\title{
Loss of viability of Mycobacterium leprae isolated from nasal secretions of lepromatous leprosy patients following daily rifampicin and DDS therapy
}

\author{
H. S. HABTE-MARIAM \& M. GUEBRE-XABIER \\ All-Africa Leprosy Rehabilitation and Training Centre (ALERT), \\ Addis Ababa, Ethiopia and Armauer Hansen Research Institute \\ (AHRI), Addis Ababa, Ethiopia
}

\begin{abstract}
Accepted for publication 6 April 1993
Summary Excreta from blowing their noses was collected from 4 previously untreated multibacillary (LL) patients in the ALERT hospital, immediately before and during daily treatment with $600 \mathrm{mg}$ rifampicin and $100 \mathrm{mg}$ dapsone (DDS). The Mycobacterium leprae recovered from the nasal secretions were enumerated and inoculated into the footpads of normal mice. Bacilli recovered from 2 of the patients failed to infect mice after 1 day's treatment, and all infectivity of the bacilli from the other 2 patients was lost after 2 days' treatment. These findings demonstrate the rapidity with which rifampicin-containing multidrug treatment is likely to reduce a patient's level of infection to their contacts.
\end{abstract}

\section{Introduction}

It is generally agreed that the nose is the main exit route of leprosy bacilli from the body..$^{1-4}$ Therefore, the quicker $M$. leprae shed from the nose lose their viability because of chemotherapy, the quicker multibacillary patients become non-infectious to their contacts. Previous studies have demonstrated that daily treatment with $600 \mathrm{mg}$ rifampicin results in extremely rapid killing of leprosy bacilli recovered from skin biopsies of multibacillary patients. ${ }^{5-6}$ Loss of infectivity for normal mice occurred within 3-7 days, the time the first post-treatment biopsies were taken, indicating that at least $99 \%$ of the initial population of viable $M$. leprae had been killed. Similar results were achieved with single doses of $1200 \mathrm{mg}$ rifampicin, while single doses of 900 and $600 \mathrm{mg}$ rifampicin were only slightly less bactericidal. ${ }^{7}$ Because there have been no parallel studies to determine how quickly $M$. leprae that have been excreted from the nose are killed by rifampicin-containing treatment, we studied the length of time taken for leprosy bacilli, recovered after the subjects had blown their noses, to lose their infectivity to normal mice. 
Table 1. Loss of infectivity of $M$. leprae isolated from nasal secretions of lepromatous leprosy patients

\begin{tabular}{lcccc}
\hline \multirow{2}{*}{$\begin{array}{l}\text { Duration of } \\
\text { treatment } \\
\text { (days) }\end{array}$} & \multicolumn{4}{c}{ Patient number } \\
\cline { 2 - 5 } & 1 & 2 & 3 & 4 \\
\hline 0 & $8 / 8$ & $8 / 8$ & $8 / 8$ & $8 / 8$ \\
1 & $0 / 8$ & $8 / 8$ & $8 / 8$ & $0 / 8$ \\
$2,3,8,15$ & $0 / 8$ & $0 / 8$ & $0 / 8$ & $0 / 8$ \\
\hline
\end{tabular}

Results are expressed as number of mice showing multiplication/number of mice inoculated with $10^{4} \mathrm{AFB}(8 / 8$ or $0 / 8)$.

\section{Materials and methods}

We selected 4 newly-diagnosed and previously untreated multibacillary patients for the study and in 199i they were admitted to the All Africa Leprosy and Rehabilitation Training Centre (ALERT) hospital for an initial period of daily treatment with $600 \mathrm{mg}$ rifampicin and $100 \mathrm{mg}$ dapsone. Nasal secretions were collected immediately before dose 1 of rifampicin (day 0 ) and 24 hours after doses 1, 2, 3, 5, 8 and 15 (days 1, 2, 3, 5, 8 and 15) by patients blowing their noses into Petri dishes. The nasal collections were decontaminated by treating with $0.5 \mathrm{~N}$ sodium hydroxide for 20 minutes and washed twice with phosphate-buffered saline (PBS) pH 7.2 at a room temperature of $21^{\circ} \mathrm{C}$. The leprosy bacilli were then pelleted by centrifugation and resuspended in $2 \mathrm{ml}$ PBS containing $0 \cdot 1 \%$ bovine serum albumin (BSA). The numbers of $M$. leprae present in each nasal excretion were determined by acid-fast staining and $8 \mathrm{BALB} / \mathrm{c}$ mice inoculated with $10^{4} \mathrm{M}$. leprae in both hind foot-pads. ${ }^{8}$ The mice were killed 6 months later, the infected foot-pads washed with alcohol, minced and then homogenized in PBS containing $0 \cdot 1 \%$ BSA until a homogeneous suspension was obtained. The number of bacteria in the homogenates were then determined after acid-fast staining. Multiplication of $M$. leprae was considered to have occurred when more than $10^{5}$ acid-fast bacilli were recovered per foot-pad.

\section{Results and Discussion}

The number of $M$. leprae recovered from each nasal excretion of the 4 patients fell $\mathrm{from}$ an average of $2.7 \times 10^{6}$ per $\mathrm{ml}$ from days $0-3$ to about $0.6 \times 10^{6}$ from days $5-15$. While the numbers of bacilli shed from each nose fell relatively slowly, the daily treatment with rifampicin and DDS caused a large fall in bacilli viability (Table 1) -i.e. as expected, bacilli from the 4 patients were infectious for mice pretreatment, but 24 hours after dose 1 leprosy bacilli recovered from 2 patients were no longer infectious and 24 hours after dose 2 and on all subsequent occasions all mouse foot-pad infectivity was lost. Because of the incubation with $\mathrm{NaOH}$, and because $M$. leprae were collected only 6 months after the mice had been inoculated, the proportions of viable organisms may have been underestimated to a small degree.

These findings are thus very similar to those previously obtained with bacilli recovered 
from skin biopsies ${ }^{5-7}$ and suggest that rifampicin-containing treatment is as effective in killing bacilli in nasal secretions as those harboured in skin lesions. They therefore indicate that the level of infection of multibacillary patients for their contacts will be rapidly reduced once chemotherapy has been initiated with the WHO-recommended multidrug treatment. ${ }^{9}$ Thus the world-wide implementation of such treatment, which has already resulted in the cure and discharge of over 3 million patients and a substantial reduction in the prevalence of the disease, ${ }^{10,11}$ may also make a significant contribution to controlling its transmission. ${ }^{12,13}$

\section{Acknowledgements}

We wish to thank Dr Felton Ross, Director of the American Leprosy Mission for his scientific advice; Dr D. Frommel, Director of AHRI; Mrs G. Vanlöv, Head of ALERT Laboratory and the technicians at the mouse foot-pad laboratory who participated in this study.

\section{References}

1 Shepard CC. The nasal secretion of Mycohacterium leprae in leprosy. Int J Lepr, 1962; 30: 10-18.

2 Davey TF, Rees RJW. The nasal discharge in leprosy: Clinical and bacteriological aspects. Lepr Rev, 1974; 45: 121-34.

${ }^{3}$ Fine PEM. Leprosy: The epidemiology of a slow bacterium. Epidemiologic Rev 1982; 4: 161-88.

4 Chehl S, Job CK, Hastings RC. Transmission of leprosy in nude mice. Am J Trop Med Hyg, 1985; 34: 1161-6.

5 Shepard CC, Levy L, Fasal P. Rapid bactericidal effect of rifampicin on Mycobacterium leprae. Am J Trop Med Hyg, 1972; 21: 446-9.

6 Shepard CC, Levy L, Fasal P. Further experience with the rapid bactericidal effect of rifampicin on Mycobacterium leprae. Am J Trop Med Hyg, 1974; 23: 1120-4.

7 Levy L, Shepard CC, Fasal P. The bactericidal effect of rifampicin on M. leprae in man. (a) Single doses of 600, 900 and $1200 \mathrm{mg}$ and (b) Daily doses of $300 \mathrm{mg}$. Int J Lepr, 1976; 44: 183-7.

${ }^{8}$ Rees RJW. Limited multiplication of acid-fast bacilli in the foot-pad of mice inoculated with Mycobacterium leprae. Br J Exp Path, 1964; 45: 207-18.

9 WHO Study Group. Chemotherapy of leprosy for control programmes. Technical Report Series No. 675. WHO: Geneva, 1982.

${ }^{10}$ Noordeen SK. Leprosy control through multidrug therapy (MDT). Bull WHO 1991; 69: $263-9$.

11 Noordeen SK, Lopez Bravo L, Sundaresan TK. Estimated number of leprosy cases in the world. Bull WHO 1992; 70: 7-10.

12 Sutherland I. The epidemiology of tuberculosis—is prevention better than cure? Bull Int Union Tuberc, 1981; 56: $127-34$

13 Sutherland I. Research on the control of tuberculosis and leprosy in the community. Brit Med Bull 1988; 44: $665-78$. 
Perte de viabilité du Mycobacterium leprae isolé des sécrétions nasales de lépreux lépromateux suite à un traitement quotidien de rifampicine et de DDS

\author{
H. S. Habte-Mariam et M. Guebre-Xabier
}

Résumé Nous avons recueilli des sécrétions nasales de quatre sujets multibacillaires (LL) précédemment non traités à l'hôpital ALERT, immédiatement avant et pendant le traitement quotidien consistant en $600 \mathrm{mg}$ de rifampicine et $100 \mathrm{mg}$ de dapsone (DDS). Le Mycobacterium leprae recueilli des sécrétions nasales a été dénombré et inoculé dans la semelle de souris normales. Les bacilles recueillis auprès de 2 sujets, n'ont pas réussi à infecter les souris suite au premier jour de traitement tandis que les bacilles provenant des 2 autres sujets avaient perdu leur infectiosité après deux jours de traitement. Ces résultats démontrent la rapidité avec laquelle un traitement médicamenteux combiné content de la rifampicine, est susceptible de réduire l'infectiosité des sujets pour les personnes qui les entourent.

\title{
Pérdida de viabilidad de los Mycobacterium leprae aislados de secreciones nasales de pacientes de lepra lepromatosa luego de terapia diaria con rifampicina y dapsona
}

\section{H. S. Habte-Mariam y M. Guebre-Xabier}

Resumen En el hospital ALERT se recogieron secreciones nasales de cuatro pacientes multibacilares (LL) no previamente tratados, inmediatamente antes y durante el tratamiento con $600 \mathrm{mg}$ de rifampicina y $100 \mathrm{mg}$ de dapsona. Los Mycobacterium leprae recuperados de las secreciones nasales fueron enumerados e inoculados en las plantas de las patas de ratones normales. Los bacilos recuperados de 2 de los pacientes no infectaron a los ratones luego del primer día de tratamiento, y el carácter infeccioso de los bacilos de los otros 2 pacientes se perdió luego de 2 días de tratamiento. Estos hallazgos demuestran la rapidez con la cual un tratamiento multidroga que contenga rifampicina puede llegar a reducir la capacidad infecciosa de los pacientes respecto de sus contactos. 